\title{
Prediction of Reservoir Performance Applying Decline Curve Analysis
}

\author{
Khulud M. Rahuma, H. Mohamed, N. Hissein, and S. Giuma
}

\begin{abstract}
Decline curve analysis is a technique can be applied to a single well, and total reservoir. Decline analysis routinely used by engineers to estimate initial hydrocarbon in place, hydrocarbon reserves at some abandonment conditions, and forecasting future production rate. The remaining reserve depends on the production points that selected to represent the real well behavior, the way of dealing with the production data, and the human errors that might happen during the life of the field. In this study the actual oil rate technique is applied under decline curve analysis (D.C.A) program, and screening data points to calculate remaining and recoverable reserves.
\end{abstract}

Index Terms-Decline curve, production history, initial decline rate, remaining reserve, scenario.

\section{INTRODUCTION}

Decline curve analysis is the most currently method used for reserve estimation when historic production data are available and sufficient [1]. The most popular decline curve is that which represent the decline in the oil or gas production rate with time, another common technique is the plot of production rates versus cumulative oil or cumulative gas production, normally termed (rate-cumulative plots). As known, oil production rate will decline with the production time increasing, when there's no other injection job. If oil rate of a production well drop to the economic limit (surface oil rate $<10 \mathrm{bbl} /$ day), the well will be considered to stop production. The two basic problems in appraisal work are the determination of most probable future life of wells and estimation of its future production.

Logical way to find an answer to the two problems mentioned, by extrapolation is to plot this variable production rate either against time or against cumulative production extending the curves thus obtained to the economic limit. The point of intersection of the extrapolated curve with the economic limit then indicates the possible future life or the future oil recovery. The basic of such an estimate is the assumption that the future behaviour of a well will be governed by whatever trend or mathematical relationship is apparent in its past performance.

This assumption puts the extrapolation method on a strictly empirical basis and it must be realized that this may make the results sometimes inferior the more exact volumetric methods [2].

Estimating oil reserves is one of the most important phases of the work of petroleum engineer since the solutions to the

Manuscript received November 9, 2012; revised February 14, 2013. This work was supported in part by the University of Tripoli.

The authors are with Petroleum Engineering (e-mail: Khulud 782000@yahoo.com). problems it deals with usually depend on a comparison of the estimated cost in terms of barrels of oil [3]. The production decline observed should truly reflect reservoir productivity and not be the result of external causes, such as a change in production conditions well damage, production controls, and equipment failure. stable reservoir condition .must also prevail in order to extrapolate decline curves with any degree of reliability this condition .will normally be met as long as the producing mechanism is not altered however, when action is taken to improve the recovery of oil ,such as infill .drilling, fluid injection, fracturing, and acidizing, decline curve analysis can be used to estimate the performance of the well or reservoir in the absence of the change and .compare it to the actual performance with the change [4]. The objectives of this study are prediction of field reserve, type of driving mechanism, and comparing the results obtained to the company results.

\section{MethodOLOGY}

The Arps equation 1945, of decline curve analysis approach was proposed more than sixty year ago. However a great number of studies on production decline analysis are still based on this empirical method. Many published papers have tried to interpret the Arps decline equation theoretically. The empirical Arps decline equation represents the relationship between production rate and time for oil wells during pseudo steady- state period and is shown as follows[5]:

The decline curve most commonly used to represent or extrapolate the production data are members of a hyperbolic family defined by the following differential equation.

$$
\frac{d}{d t}\left(\frac{q}{d q / d t}\right)=-b \Rightarrow
$$

where:

$q$ : oil production rate .

$b$ : reservoir Factor

Direct integration of equation (1) gives:

$$
\frac{q}{d q / d t}=-b t-\frac{1}{a_{i}} \Rightarrow
$$

where:

$a_{i}$ : nominal Decline Rate

$t$ : time

The constant "b" is a reservoir constant, which international oil field experience has shown its value to be normally between 0 and 1.0. Equation 2, can be easily integrated using the initial condition of $q=q_{i}$ at time $t=0$, to give the following general form for production decline in oil 
reservoir:

$$
q=\frac{q_{i}}{\left(1+a_{i} b t\right)^{1 / b}} \Rightarrow
$$

where:

$q_{i}$ : Initial oil production rate

Some investigators claim that the value of "b" is directly proportional to the back-pressure test log-log exponent (n).

The three commonly recognized types of decline curves: Constant percentage decline (exponential decline), Harmonic decline, and Hyperbolic decline.

Two main fitting techniques are popular with petroleum engineers; the first is normally used in case of small number of data point, only a pocket calculator is available. It is known as .the "Average lines method". The second and more popular method is known as the "least sum of square method". As the name implies, it required that the sum of the square of the discrepancies between the actual and calculated value must be a minimum.

This method has many advantages:

1) The equations are simple and their application required only a pocket calculator. It's also available as a direct function on the Microsoft Excel.

2) This method can be used easily to fit the data points to any form of equations.

3) Finally, it has proven to be the most "reliable" tool for extrapolation out said the range of the measured data in most engineering and scientific problems.
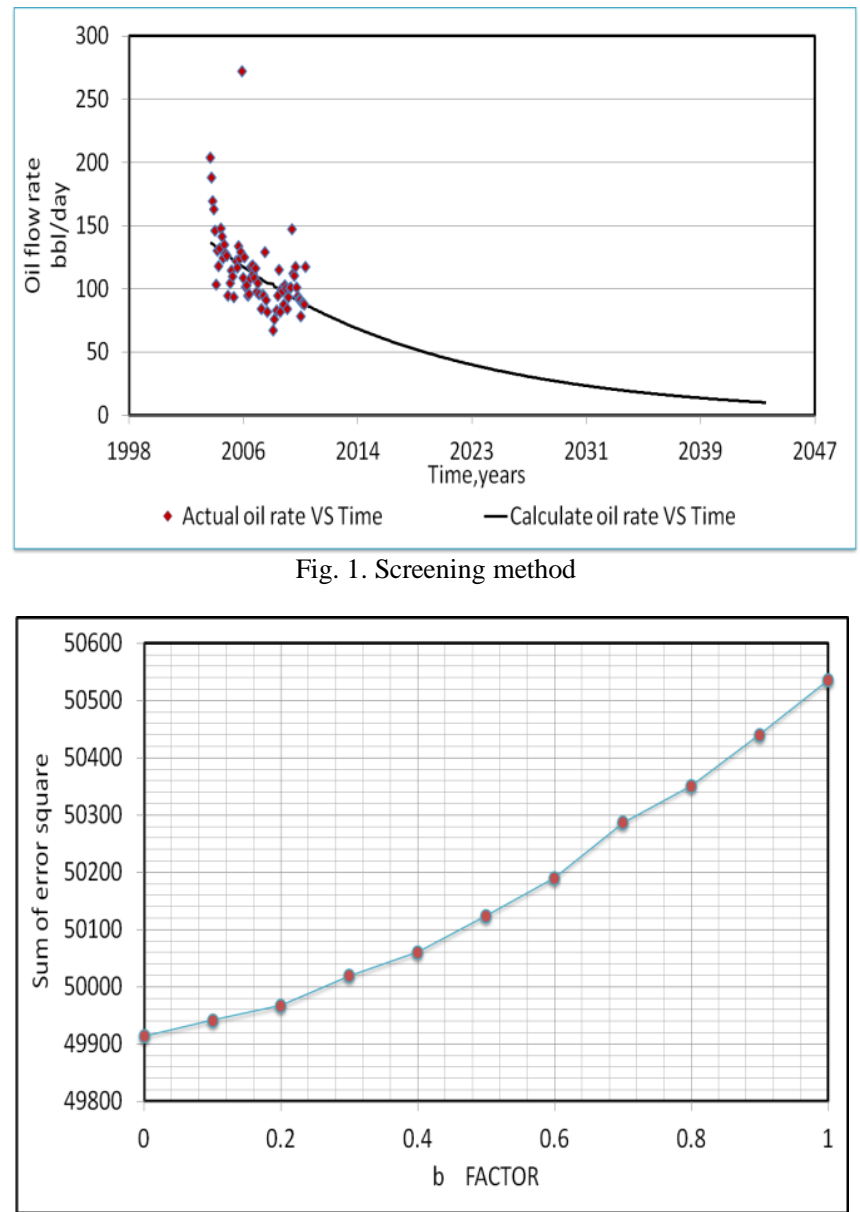

Fig. 2. Sum error square .vs .b factor

\section{DISCUSSION AND RESULTS}

In this study decline analysis was applied for wells, and whole field.

\section{A. Wells Decline Curve Analysis}

The remaining reserve calculation becomes more reliable whenever data points are well screening. The decline type of well 1 is exponential, and the remaining reserve calculated from end period $(5 / 31 / 2004$ to $3 / 31 / 2011)$ to economic limit is $.596,738$ bbl. Fig. 1 represents screening method, Fig. 2 shows sum error square. vs. b factor, as well as Table. I include economic recoverable reserves, abandonment time, initial decline using D.C.A. program, and Hand calculations.

TABLE I: RESULTS OF WELL 1

\begin{tabular}{|c|c|c|}
\hline $\begin{array}{c}\text { Cut-off Criteria: } 15 \\
\text { bbl/day } \\
\text { Correlated period: .from } \\
5 / 31 / 2004 \text {.to .3/31/2011 }\end{array}$ & $\begin{array}{c}\text { Hand } \\
\text { calculation }\end{array}$ & $\begin{array}{c}\text { D.C.A } \\
\text { program }\end{array}$ \\
\hline $\begin{array}{c}\text { Decline Exponent } \\
\begin{array}{c}\text { Decline Factor } \\
\text { (1/month) }\end{array}\end{array}$ & 0.00456 & 0.005507 \\
\hline $\begin{array}{c}\text { Initial Decline Rate } \\
\text { (bbl/day) }\end{array}$ & 138 & 138 \\
\hline $\begin{array}{c}\text { Economic Recoverable } \\
\text { Reserves (bbl) }\end{array}$ & 568,884 & 564,458 \\
\hline $\begin{array}{c}\text { Abandonment Time } \\
\text { (years) }\end{array}$ & 33.831 & 33.61 \\
\hline \multicolumn{2}{|c|}{} \\
\hline
\end{tabular}

Well 2 decline type is exponential in period from $11 / 30 / 2002$ to $3 / 31 / 2011$, where the remaining reserve calculated from end period to economic limit is 529, $941 \mathrm{bbl}$. Fig. 3 represents screening method, Fig. 4 shows sum error square .vs .b factor, as well as TABLE II includes economic recoverable reserves, abandonment time, initial decline using D.C.A. program, and Hand calculations.

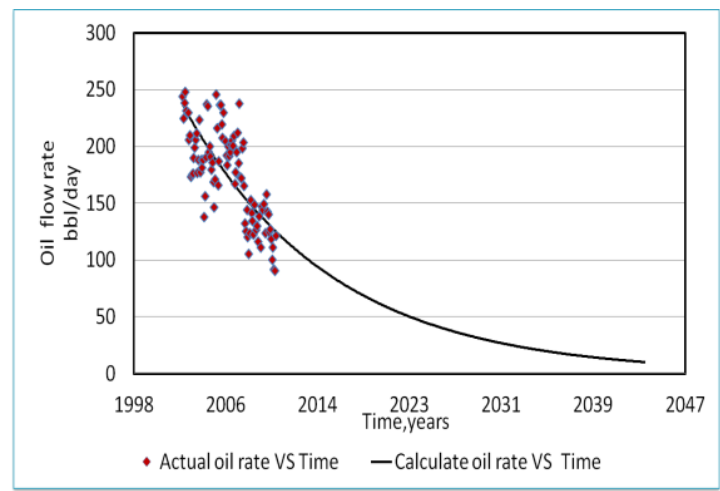

Fig. 3. Screening method

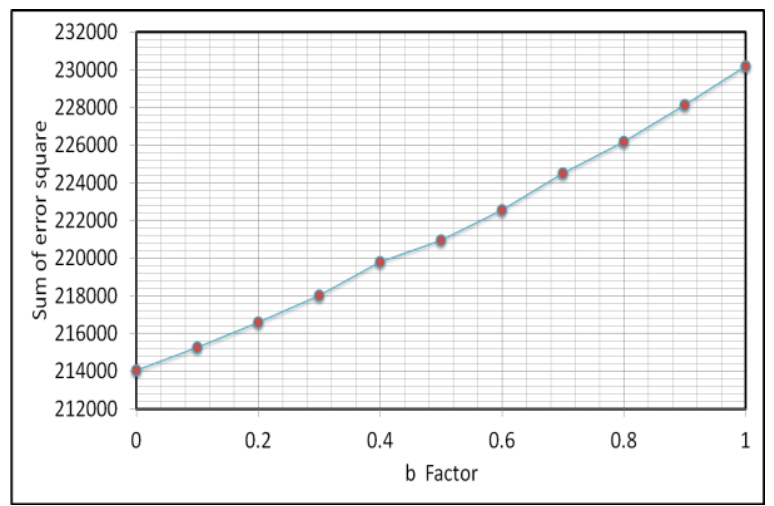

.Fig. 4. Sum error square .Vs .b factor 
Well 3 study period from 7/31/2002 to 3/31/2011, shows the decline type is hyperbolic, and the remaining reserve calculated from end period to economic limit is $546,768 \mathrm{bbl}$ Fig. 5 represents screening method, Fig. 6 shows sum error square .vs .b factor, as well as TABLE. III includes economic recoverable reserves, abandonment time, initial decline using D.C.A. program, and Hand calculations.

\begin{tabular}{|c|c|c|}
\hline \multicolumn{4}{|c|}{ TABLE II: RESULTS OF WELL 2} \\
$\begin{array}{c}\text { Cut-off } \\
\text { Criteria:15 .bbl/day } \\
\text { Correlated period: .from } \\
\text { 11/30/2002 .to : 3/31/2011 }\end{array}$ & $\begin{array}{c}\text { Hand } \\
\text { calculation }\end{array}$ & $\begin{array}{c}\text { D.C.A } \\
\text { program }\end{array}$ \\
\hline $\begin{array}{c}\text { Decline Exponent } \\
\text { Decline Factor } \\
\text { (1/month) }\end{array}$ & 0.00638 & 0.006377 \\
\hline $\begin{array}{c}\text { Initial Decline Rate } \\
\text { (bbl/day) }\end{array}$ & 238 & 238 \\
\hline $\begin{array}{c}\text { Economic Recoverable } \\
\text { Reserves (bbl) }\end{array}$ & 506,104 & 506,291 \\
\hline $\begin{array}{c}\text { Abandonment Time } \\
\text { (years) }\end{array}$ & 36.118 & 36.131 \\
\hline
\end{tabular}
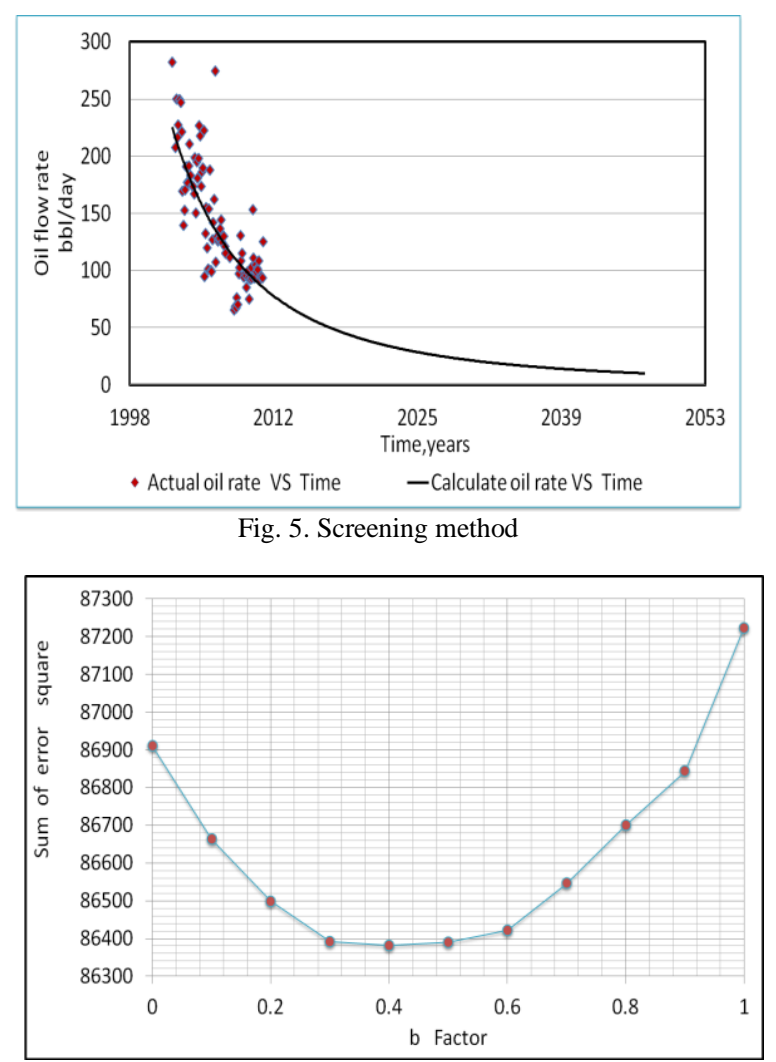

Fig. 6. Sum error square .Vs .b factor

TABLE III: RESULTS OF WELL 3

\begin{tabular}{|c|c|c|}
\hline $\begin{array}{c}\text { Cut-off Criteria:15 .bbl/day } \\
\text { Correlated period: .from } \\
7 / 31 / 2002 \text {.to }: 3 / 31 / 2011\end{array}$ & $\begin{array}{c}\text { Hand } \\
\text { calculation }\end{array}$ & $\begin{array}{c}\text { D.C.A } \\
\text { program }\end{array}$ \\
\hline Decline Exponent & 0.4 & 0.4 \\
\hline $\begin{array}{c}\text { Decline Factor } \\
\text { (1/month) }\end{array}$ & 0.011519 & 0.01151 \\
\hline $\begin{array}{c}\text { Initial Decline Rate } \\
\text { (bbl/day) }\end{array}$ & 228 & 228 \\
\hline $\begin{array}{c}\text { Economic Recoverable } \\
\text { Reserves (bbl) }\end{array}$ & 504,415 & 504,842 \\
\hline $\begin{array}{c}\text { Abandonment Time } \\
\text { (years) }\end{array}$ & 38.44 & 35.679 \\
\hline
\end{tabular}

From study period (3/31/1999 to $3 / 31 / 2011)$ of well 4 , the decline type is hyperbolic, and the remaining reserve calculated from end period to economic limit is $.547,819 \mathrm{bbl}$. Fig. 7 represents screening method, Fig. 8 shows sum error square .vs .b factor, as well as TABLE. IV includes economic recoverable reserves, abandonment time, initial decline using D.C.A. program, and Hand calculations.

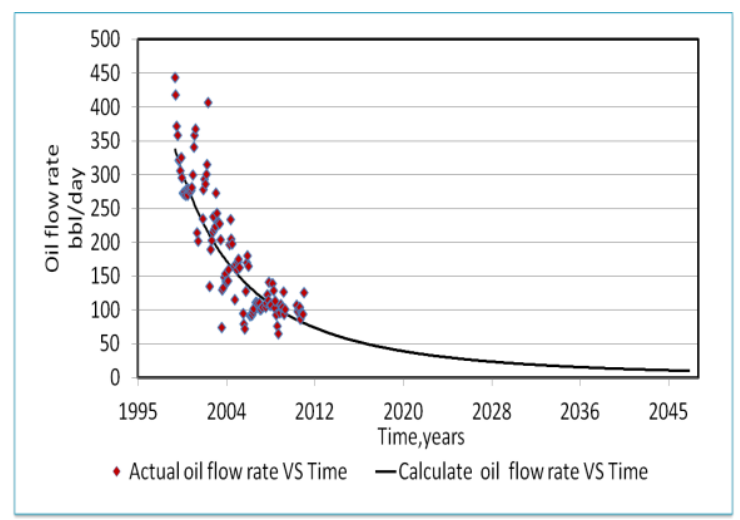

Fig. 7. Screening method
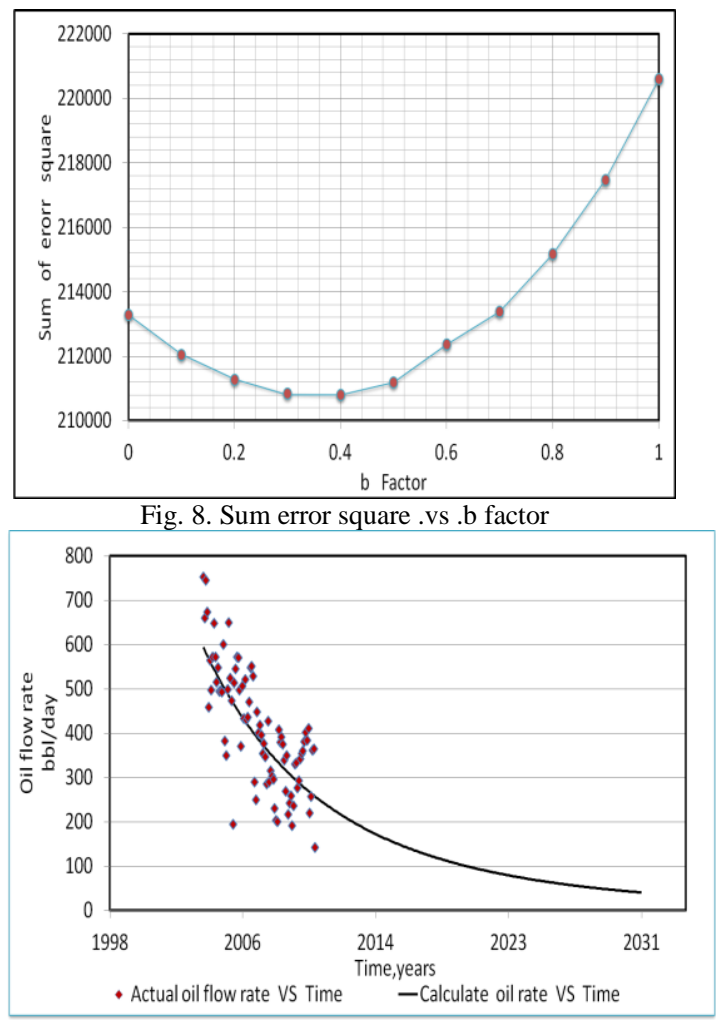

Fig. 9. Screening method

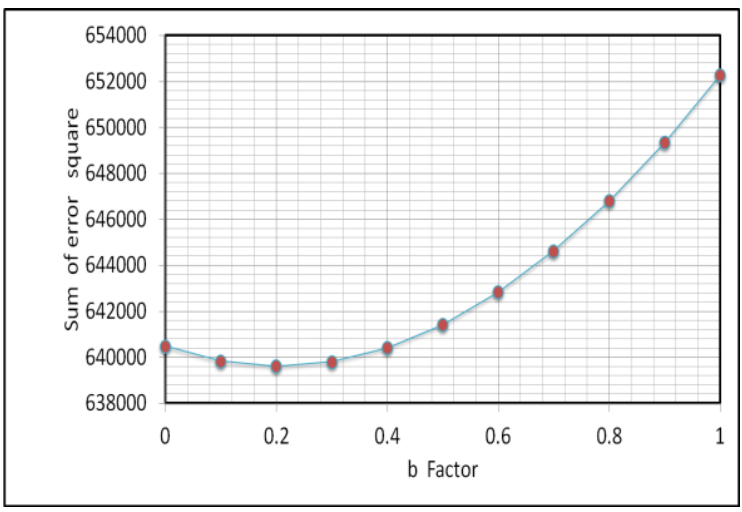

Fig. 10. Sum error square .vs .b factor

B. Decline Curve Analysis for the Whole Field

The decline type of the field is hyperbolic, the remaining 
reserve calculated from end of period to economic limit(from .3/31/1999 to .3/31/2011) is 575, 480 bbl. Fig. 9 represents screening method, Fig. 10 shows sum error square .vs .b factor, as well as TABLE. V includes economic recoverable reserves, abandonment time, initial decline using D.C.A. progam, and Hand calculations.

Comparing remaining .reserve of whole field with sum of a wells is $303,599 \mathrm{bbl}, 2,084,788 \mathrm{bbl}$ respectively. There is big difference equal $1,781,189 \mathrm{bbl}$, due to shutting some wells in time of calculating remaining .reserve, therefore it is necessary to select well by well method during the calculation of decline curve analysis.

\begin{tabular}{|c|c|c|}
\hline $\begin{array}{l}\text { Cut-off Criteria: } 60 \text {.bbl/day } \\
\text { Correlated period:from } \\
\text { 4/30/2004 .To : } 3 / 31 / 2011\end{array}$ & $\begin{array}{c}\text { Hand } \\
\text { calculation }\end{array}$ & $\begin{array}{l}\text { D.C.A } \\
\text { program }\end{array}$ \\
\hline Decline Exponent & 0.2 & 0.2 \\
\hline $\begin{array}{l}\text { Decline Factor } \\
(1 / \text { month })\end{array}$ & 0.01101 & 0.011007 \\
\hline $\begin{array}{l}\text { Initial Decline Rate } \\
\text { (bbl/day) }\end{array}$ & 601 & 601 \\
\hline $\begin{array}{l}\text { Economic Recoverable } \\
\text { Reserves (bbl) }\end{array}$ & 325,369 & 324,278 \\
\hline $\begin{array}{c}\text { Abandonment Time } \\
\text { (years) }\end{array}$ & 22.145 & 22.197 \\
\hline
\end{tabular}

TABLE IV: RESULTS OF WELL4

\begin{tabular}{|c|c|c|}
\hline $\begin{array}{c}\text { Cut-off Criteria:15 bbl/day } \\
\text { Correlated period: from } \\
31 / 30 / 1999 \text {.to }: 3 / 31 / 2011\end{array}$ & $\begin{array}{c}\text { Hand } \\
\text { calculation }\end{array}$ & $\begin{array}{c}\text { D.C.A } \\
\text { program }\end{array}$ \\
\hline Decline Exponent & 0.4 & 0.4 \\
\hline $\begin{array}{c}\text { Decline Factor } \\
\text { (1/month) }\end{array}$ & 0.013532 & 0.013534 \\
\hline $\begin{array}{c}\text { Initial Decline Rate } \\
\text { (bbl/day) }\end{array}$ & 342 & 343 \\
\hline $\begin{array}{c}\text { Economic Recoverable } \\
\text { Reserves (bbl) }\end{array}$ & 505,385 & 505,411 \\
\hline $\begin{array}{c}\text { Abandonment Time } \\
\text { (years) }\end{array}$ & 38.44 & 38.446 \\
\hline
\end{tabular}

\section{CONCLUSION}

The value of reservoir factor (b) is equal to 0.2 which means, that the drive mechanism in the reservoir is a combination drive. The difference from one well to another indicates, that the wells are far from the injector wells. Analysis by D.C.A program takes less time comparing with hand analysis. The calculated remaining reserve is equal $325,369 \mathrm{bbl}$. The recoverable reserves estimated, cannot be recovered completely using the existing wells due to a number of wells were shut in for mechanical problems (i.e. ESP failure). It is .recommended to work over there wells, and drill more infill wells to maximize oil recovery. Also it is recommended to optimize the water injection because the water injection will be partially affect water cut during oil production in reservoir, and a comprehensive DCA should be performed to see the effect of the orations procedure on the remaining reserves.

\begin{tabular}{|ccc|}
\multicolumn{3}{|c}{ NOMENCLATURE } \\
\hline Symbol & Definition & Units \\
\hline$a_{i}$ & Nominal Decline Rate & 1/year \\
\hline$B$ & Reservoir Factor & Unit less \\
\hline & $\begin{array}{c}\text { Oil production rate at } \\
\text { time } t\end{array}$ & BBL/Day \\
\hline & $\begin{array}{c}\text { Initial oil production } \\
\text { rate }\end{array}$ & BBL/Day \\
\hline$q_{i}$ & & \\
& & \\
& &
\end{tabular}

\section{REFERENCES}

[1] F. Brons, "On the Use and Misuse of Production Decline Curves," Producers Monthly, 1963.

[2] J. J. Arps, "Analysis of Decline Curves," Trans. AIME, vol. 160, pp. 228-247, 1945.

[3] C. W. N. Jr, "Estimation of Underground Oil Reserves by Oil-Well Production Curves," USBM Bull, vol. 228, 1924.

[4] B. K. Vansandt et al., Gaudiness for application definitions for oil and gas reserves, December. 1988.

[5] J. M. Campbell, Oil Property Evaluation, Prentice Hall, Inc, Englewood Cliffs, 1960.

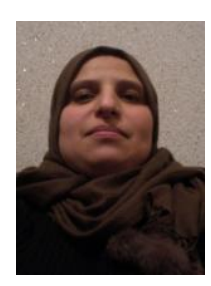

Khulud M. Rahuma is currently working in the University Of Tripoli. Also she is a coordinator Curricula and Arabicizing of Petroleum Department since 2008 till now. Dean of Study Program at Faculty of Engineering Tripoli since 2010 up to now. She received Philosophy Doctor $(\mathrm{PhD})$ in Petroleum Engineering and Management. She was Selected for Well Planning Symposium held by Azerbaijan SPE Chapter 27-28th .October 2005, and April 2007.

She is a member of the Committee in the First Competition of Student Research Papers at the level of the Arab Maghreb, SPE Libyan Section 2010 . 